\title{
Soft Tissue Sarcoma of the Trunk and Extremities pN0 TNM Finding v8
}

National Cancer Institute

\section{Source}

National Cancer Institute. Soft Tissue Sarcoma of the Trunk and Extremities pNO TNM

Finding v8. NCI Thesaurus. Code C136690.

Soft tissue sarcoma of the trunk and extremities without regional lymph node metastasis or unknown lymph node status. (from AJCC 8th Ed.) 